\title{
Growth of Octopus vulgaris (Cuvier, 1797) in tanks in the Ebro Delta (NE Spain): effects of temperature, salinity and culture density
}

\author{
MARINA DELGADO $^{1}$, JOAN IGNASI GAIRÍN ${ }^{2}$, RICARD CARBÓ $^{2}$ \\ and CRISTÓBAL AGUILERA ${ }^{2}$ \\ ${ }^{1}$ Instituto Español de Oceanografía. Centro Oceanográfico de Cádiz. Muelle de Levante s/n., P.O. Box 2609. \\ E-11006 Cádiz, Spain. E-mail: marina.delgado@cd.ieo.es \\ ${ }^{2}$ Institut de Recerca i Tecnologia Agroalimentaries. Centre de Aqüicultura. Carretera del Poble Nou, Km 5.5. \\ E-43540 Sant Carles de la Rápita, Tarragona, Spain.
}

\begin{abstract}
SUMMARY: To assess the possibility of $O$. vulgaris ongrowing using tanks or cages in the bays of the Ebro Delta, we performed several growth trials of common octopus held in tanks. Effects of environmental factors (temperature and salinity) and zootechnical aspects (culture density) were studied. The thermal ranges that defined positive growth periods in the bays of the Ebro Delta were $19.5^{\circ} \mathrm{C}$ to $23^{\circ} \mathrm{C}$ (spring-summer) and $23.5^{\circ} \mathrm{C}$ to $12.3^{\circ} \mathrm{C}$ (autumn-winter), the latter being the most suitable period for ongrowing. Salinity did not affect survival (100\%) or growth within the range tested (34-29 psu), though feeding rates (AFR, SFR) were directly related to salinity. On the other hand, after 60 days, final culture density increased three-fold (D1: $12.36 \rightarrow 44.37 \mathrm{~kg} \mathrm{~m}^{-3}$; D2: $24.13 \rightarrow 67.76 \mathrm{~kg} \mathrm{~m}^{-3}$ ), with optimal survival results $(>90 \%)$ for the two densities tested. Growth and feeding rates showed a slight inverse relationship with density. Finally, growth and feeding rates showed a clear dependence on temperature in the two experiments (density and salinity). Our results conclude that industrial production of $O$. vulgaris in tanks is promising: this system offers an alternative to cages and allows for a more exhaustive control of culture.
\end{abstract}

Keywords: Octopus vulgaris, growth, ongrowing, temperature, salinity, culture density.

RESUMEN: Crecimiento de Octopus vulgaris (Cuvier, i797) en tanque en el Delta del Ebro (NE España): EfecTOS DE LA TEMPERATURA, SALINIDAD Y DENSIDAD DE CULTIVO. - Con el fin de evaluar la posibilidad de engorde de $O$. vulgaris en tanques o jaulas en las bahías del Delta del Ebro, se llevaron a cabo varias experiencias de crecimiento de individuos mantenidos en tanques. Se estudiaron tanto aspectos medioambientales (temperatura y salinidad) como zootécnicos (densidad de cultivo). Los rangos térmicos que definieron periodos positivos de crecimiento en las bahías del Delta del Ebro fueron: $19.5^{\circ} \mathrm{C}-23^{\circ} \mathrm{C}$ (primavera-verano) y $23.5^{\circ} \mathrm{C}-12.3^{\circ} \mathrm{C}$ (otoño-invierno), siendo este último el periodo más favorable para el engorde. La salinidad no afectó a la supervivencia o al crecimiento dentro del rango testado (34-29 psu), a pesar de que las tasas de alimentación (AFR, SFR) mantuviesen relación directa con la salinidad. Por otro lado, y transcurridos 60 días, observamos que la densidad de cultivo se multiplicó por tres (D1: $12.36 \rightarrow 44.37 \mathrm{~kg} \mathrm{~m}^{-3}$; D2: $24.13 \rightarrow 67.76 \mathrm{~kg} \mathrm{~m}^{-3}$ ), con resultados óptimos de supervivencia $(>90 \%)$ bajo las dos condiciones probadas. Las tasas de crecimiento y alimentación mostraron una relación indirecta con la densidad de cultivo. Finalmente, se observó que tanto las tasas de crecimiento como las de alimentación presentan una clara dependencia de la temperatura en ambas experiencias (salinidad y densidad de cultivo). Nuestros resultados concluyen que la producción industrial de $O$. vulgaris en tanques es prometedora: este sistema ofrece una alternativa a las cajas y permite un control más exhaustivo del cultivo.

Palabras clave: Octopus vulgaris, crecimiento, engorde, temperatura, salinidad, densidad de cultivo.

\section{INTRODUCTION}

In recent years, Octopus vulgaris has become a species of increasing interest for aquaculture due mainly to its high growth and food conversion rates, high market prices, and increasing demand. Many ongrowing studies using floating cages or tanks have been carried out along the Spanish coast (García and Aguado, 2002; 
Iglesias et al., 2004; Chapela et al., 2006) but, to date, few ongrowing experiments in tanks on an industrial scale have been done. The octopus is inherently a territorial species and requires a minimum space for its development and growth. Most previous studies of octopus ongrowing in tanks have focused on physiological and nutritional aspects with octopuses being placed individually in tanks. However, little information is available about ongrowing of octopuses kept together (Iglesias et al., 1997; García and Cerezo, 2004), as was done in our experiments.

In most poikilotherm species, such as fish and molluscs, growth, food intake, and survival have an optimum temperature (Brett, 1979; Aguado and García, 2002). Defining the optimal temperature range is essential for the success of the ongrowing phase. Of similar importance is the selection of places where the stability of the ongrowing structures can be established. The protected areas of the bays of the Ebro Delta appear suitable for culture in floating cages. However, these bays experience large variations of physical-chemical parameters over the year due to their dimensions (12 $\mathrm{km}^{2}$ for Fangar bay and $50 \mathrm{~km}^{2}$ for Alfacs bay, with a maximum depth of $6 \mathrm{~m}$ for both bays). Generally, thermal oscillation is high, and water renewal periods are about 1-2 days in Fangar bay and 10 days in Alfacs bay (Camp and Delgado, 1987). The critical temperature values reached during summer in the bays of the Ebro Delta affect growth and survival dynamics of bivalve molluscs (Ramón et al., 2007). Furthermore, heavy rainfall and discharges from the Ebro river and nearby rice-growing areas substantially increase the input of fresh water into the bay and, consequently, affect salinity levels (Fernández and Diogène, 2008). Most cephalopods are stenohaline organisms and poor osmoregulators (Boletzky and Hanlon, 1983), and low salinity appears to induce their migration to deeper waters (Hartwick et al., 1984). The strong fluctuations of both temperature and salinity could condition the periods of culture viability and the selection of an appropriate location for their culture in tanks or floating cages.

The main objective of this work was to ascertain the optimal environmental range (temperature and salinity) for $O$. vulgaris growth in tanks and for future floating cages in the Ebro Delta. In addition, we intended to carry out trials with an industrial approach, providing information about the production of the common octopus under confinement conditions.

\section{MATERIALS AND METHODS}

Octopuses (O. vulgaris) were caught in the coastal waters of Sant Carles de la Rápita (NW Mediterranean, near the Ebro Delta, Fig. 1) using trawl nets and shelter lines. From the port to the laboratory (IRTA), octopuses were transported in $1000 \mathrm{~L}$ tanks in seawater supplied with oxygen. The experiments began once the octopus had acclimatized in $1000 \mathrm{~L}$ tanks (2 weeks). Fish (Boops boops or Mugil cephalus) and crab (Carci-

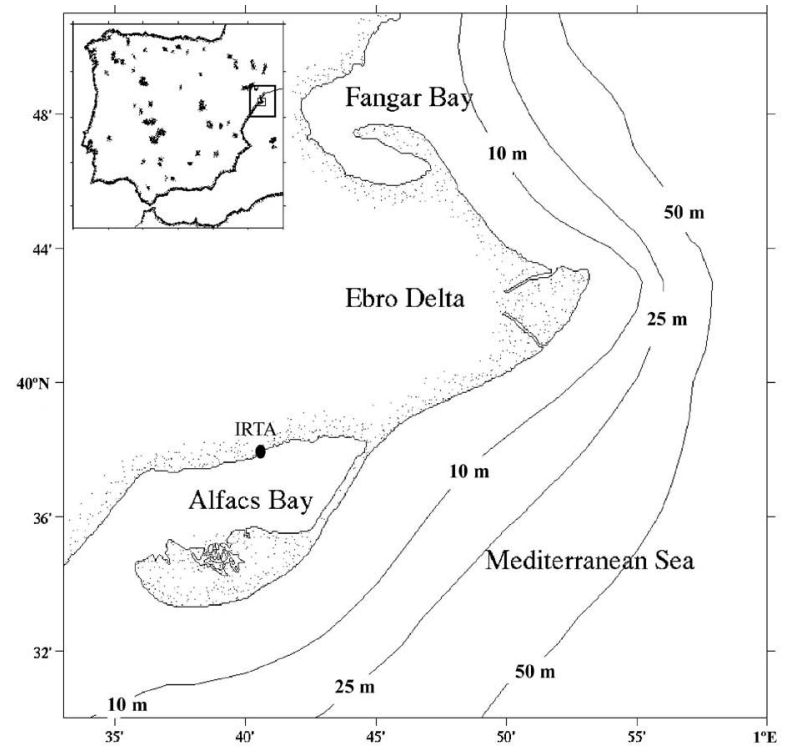

FIG. 1. - Map of the Ebro Delta showing the site (IRTA, Alfacs Bay) at which the experiments were conducted.

nus sp.) were supplied on alternate days before the experiments started.

\section{Experimental design}

Several experiments were carried out in tanks in the period 2006-2008. First, as a preliminary step, we determined suitable thermal periods for octopus ongrowing in the Ebro Delta. Then, the effects of salinity and culture density on $O$. vulgaris growth in tanks were tested in the most suitable thermal period. The experiments consisted of groups of more than 5 individuals per tank and lasted at least until the octopuses reached commercial size $(>2 \mathrm{~kg})$. Food diets were calculated to get ad libitum rations. Crab was introduced in the diet to abate aggressiveness and cannibalism (García and Cerezo, 2006). For all trials, we used an open flow-through system and seawater taken directly from Alfacs Bay (Fig. 1).

Since Aguado and García (2002) did not detect differences in the growth between males and females, it was decided not to separate sexes. The sex ratio was 1:1 $(P<0.01)$ in all experiments. Octopus sizes corresponded to adults and sexual maturation and fertilization could have taken place (Tirado et al., 2003). To prevent the effect of spawning on female growth (and consequently on the average growth of the experimental group), shelters were inspected daily. Only on one occasion was a spawning detected. Immediately, this female and her eggs were withdrawn and replaced with another individual of the same weight.

\section{Experiment 1: Effects of temperature}

Growth of $O$. vulgaris was studied under two different temperature regimes. Trial 1 comprised a period 
of temperature increase (from 8 May 2006 to 31 July 2006: spring-summer period, 84 days). Trial 2 comprised a period of temperature decrease (from 29 September 2006 to 27 February 2007: fall-winter period, 151 days). In both cases, salinity was $34.7 \pm 1$ psu. For each trial, 15 octopuses (O. vulgaris) were placed in a $1500 \mathrm{~L}$ tank, containing a radially disposed structure with 16 PVC tubes as shelters. Diet (10\% of biomass) consisted of bogue (B. boops) and crab (Carcinus sp.) $(1: 1)$ and was supplied 6 days per week.

\section{Experiment 2: Effects of salinity}

The experiment started on 21 October 2008 and lasted 58 days. Salinity was measured in practical salinity units (psu). The selection of salinity values was based on the following information: 1) the salinity range compatible with life described by Mangold (1983) is 3240 , and 2) the lowest salinity value recorded in Alfacs bay at a depth $(1.5 \mathrm{~m})$ where ongrowing cages could be placed in the future is 28 (Fernández and Diogène, 2008). Therefore, the following three water salinities were tested: salinity 1 (S1; 34, control), salinity 2 (S2; $31.5)$, and salinity 3 (S3; 29). Salinity was maintained by mixing freshwater and seawater with a regulator PID GFE 210 (GF pumping systems) equipped with a GFE 210 conductivity probe (GEORGE Fisher S.A.). For each salinity, three replicates were tested. Each replicate consisted of 5 octopuses per 650-L tank. Tanks contained rectangular structures with 12 PVC tubes as shelters. Diet (10\% of biomass) included fish (B. boops and $M$. cephalus) and crab (Carcinus sp.) and was supplied 6 days per week at a proportion of 2:1 (fish:crab).

\section{Experiment 3: Effects of culture density}

The experiment started on 19 September 2007 and lasted 60 days. Salinity was $34.7 \pm 1$. Two different initial culture densities were tested: D1 $\left(12 \mathrm{~kg} \mathrm{~m}^{-3}\right)$ and D2 $\left(24 \mathrm{~kg} \mathrm{~m}^{-3}\right)$. Three replicates with 10 (D1) or 20 (D2) octopuses each were placed in 650-L tanks. The tanks contained rectangular structures with 12 (D1) and 24 (D2) PVC tubes as shelters. Diet (10\% of biomass) included fish (B. boops and M. cephalus) and crab (Carcinus sp.) and was supplied 6 days per week at a proportion of 2:1 (fish:crab).

\section{Parameter measurements}

In all trials, weight was used to assess growth in $O$. vulgaris. Initial ( $\mathrm{Wi}=$ initial weight in $\mathrm{g}$ ) and final (Wf = final weight in $\mathrm{g}$ ) weights were recorded for all experiments. Additionally, data were taken every 20 days for Experiment 1, and a midpoint sampling was performed on day 29 for Experiment 2. Every tank provided average data of weight. Two growth indices were calculated: Absolute growth rate $\left(\mathrm{AGR}=(\mathrm{Wf}-\mathrm{Wi}) / \mathrm{t} ; \mathrm{g} \mathrm{day}^{-1}\right)$ and specific growth rate $(\mathrm{SGR}=(\mathrm{LnWf}-\mathrm{LnWi}) 100 / \mathrm{t} ; \%)$, with $\mathrm{t}=$ time between two measurements in days.
Ingested food (IF; g) was calculated daily as follows: Food was weighed and provided every day, and uneaten food was taken out, allowed to drain and weighed the following day to calculate (as the difference) the exact amount of food eaten (García and Aguado, 2002). In the case of crabs, the edible fraction was estimated as 50\% (García and Cerezo, 2006). The following feeding indices were calculated: absolute feeding rate $\left(\mathrm{AFR}=\mathrm{IFs} / \mathrm{t} ; \mathrm{g} \mathrm{day}^{-1}\right)$ and specific feeding rate $($ SFR $=$ AFR $100 / \mathrm{Wa} ; \%)$, with $\mathrm{IFs}=$ total sum of daily IF and $\mathrm{Wa}=$ average weight from initial and final measures in $g$. To analyze the variation in ingestion during the experiment the instantaneous specific feeding rate $(\mathrm{IFR}=\mathrm{IF} / \mathrm{Wd} * 100 ; \%)$ was calculated on a daily basis, with $\mathrm{Wd}=$ estimation of daily weight from SGR values.

Survival (S; \%) was also evaluated in each sampling. In all trials, water temperature, salinity and dissolved oxygen were recorded twice per day (8:00 a.m. and 3:00 p.m.). Three times a week, levels of $\mathrm{pH}$ and ammonium were measured. Dissolved oxygen was maintained above $75 \%$, so this was not a limiting factor (Cerezo and García, 2005).

\section{Data analysis}

Comparisons between experimental conditions or samplings were performed by a $t$ test or ANOVA, complemented by a multiple range test (LSD). Homogeneity of variances was tested by Cochran's test (Snedecor and Cochran, 1980). Correction for heterogeneity (when required) was performed by reciprocal or logarithmic data transformation. Angular transformation (arcsine $\sqrt{\%}$ ) was applied to parameters expressed as percentages. Tests were performed using Statgraphics 5.1 software.

\section{RESULTS}

\section{Effects of temperature}

Trial 1 (spring-summer period) started at $19.5^{\circ} \mathrm{C}$ and ended 84 days later at $29.2^{\circ} \mathrm{C}$. Initial weight was $731.7 \pm 325.9 \mathrm{~g}$ (Fig. 2A). Values in excess of $2200 \mathrm{~g}$ were reached from day 42 and remained approximately constant until day 70 (thermal range: $24.4-28.4^{\circ} \mathrm{C}$ ) (Fig. 2C. ANOVA, $P=0.00$; LSD test for $95 \%$ significance level). After this date, high mortality (88\%) and weight losses were recorded, coinciding with a period of 2 weeks with temperatures in excess of $28^{\circ} \mathrm{C}$.

Trial 2 (autumn-winter period) started at $23.5^{\circ} \mathrm{C}$ and ended 151 days later at $13.4^{\circ} \mathrm{C}$. Temperatures below $10^{\circ} \mathrm{C}$ were recorded twice during this period (Fig. 2B). Accumulated mortality reached $47 \%$. Initial weight was $702.0 \pm 279.3 \mathrm{~g}$, and a maximum weight of $4650.6 \pm$ $1044.9 \mathrm{~g}$ was recorded at the end of the assay. From day 66 , the growth rate declined, and no significant growth was recorded in the last three samplings (Fig. 2D. ANOVA, $P=0.00$; LSD test for $95 \%$ significance level). 
TABLE 1. - Mean values \pm SD of every index for each experimental group in Experiment 2 (effects of salinity). Wi, initial weight; Wf, final weight; S, survival; AGR, absolute growth rate; SGR, specific growth rate; AFR, absolute feeding rate; SFR, specific feeding rate. LSD, multiple range test; $n . s .=$ not significant.

\begin{tabular}{|c|c|c|c|c|}
\hline & S1 (34) & $\mathrm{S} 2(31.5)$ & S3 (29) & ANOVA (p); LSD \\
\hline Wi (g) & $1087.00 \pm 251.60$ & $904.00 \pm 267.73$ & $995.07 \pm 261.84$ & n.s. \\
\hline $\mathrm{Wf}(\mathrm{g})$ & $2324.93 \pm 458.95$ & 2064.40634 .84 & 2233.00439 .27 & n.s. \\
\hline $\mathrm{S}(\%)$ & 100 & 100 & 100 & \\
\hline $\operatorname{AGR}\left(\mathrm{g} \mathrm{day}^{-1}\right)$ & $22.25 \pm 0.44$ & $20.72 \pm 1.92$ & $22.11 \pm 1.16$ & n.s. \\
\hline $\operatorname{SGR}(\%)$ & $1.36 \pm 0.02$ & $1.47 \pm 0.12$ & $1.44 \pm 0.05$ & n.s. \\
\hline $\operatorname{AFR}\left(\mathrm{g} \mathrm{day}^{-1}\right)$ & $38.35 \pm 1.46$ & $40.15 \pm 2.44$ & $31.86 \pm 2.28$ & $<0.05(\mathrm{~S} 1 \neq \mathrm{S} 3 ; \mathrm{S} 2 \neq \mathrm{S} 3)$ \\
\hline $\operatorname{SFR}(\%)$ & $2.17 \pm 0.15$ & $2.47 \pm 0.23$ & $1.92 \pm 0.10$ & $<0.05(\mathrm{~S} 2 \neq \mathrm{S} 3)$ \\
\hline
\end{tabular}

A Trial 1: Spring-Summer
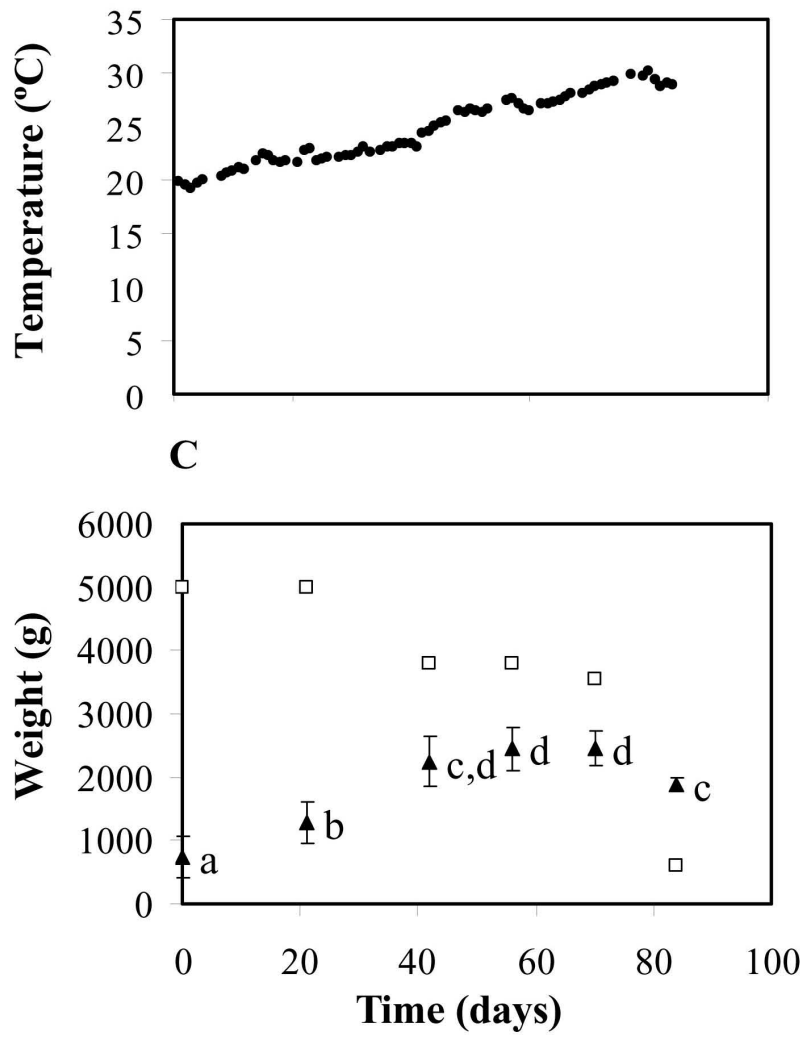

B Trial 2: Autumn-Winter

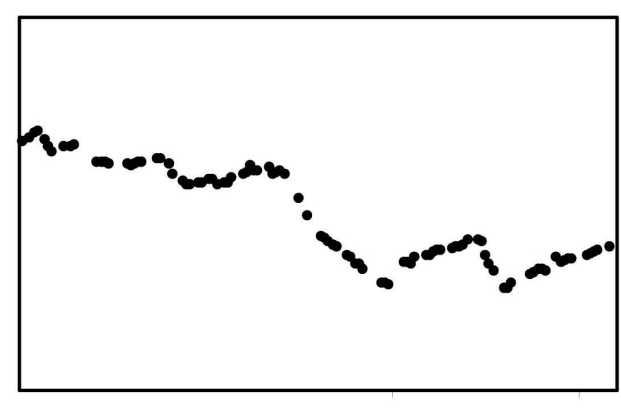

D

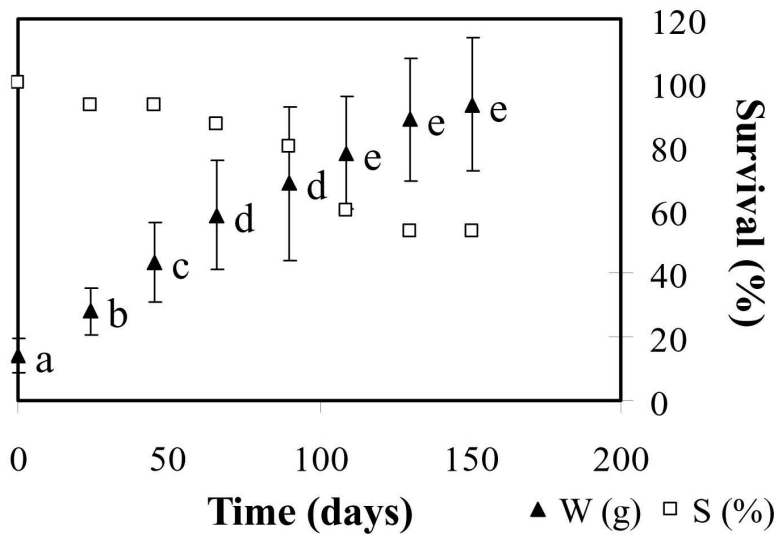

FIG. 2. - A and B, daily water temperature during the two trials (Experiment 1: effects of temperature). C and D, variation of octopus mean weight $(\mathrm{W}) \pm \mathrm{SD}$ and survival (S) during the different thermal periods. Graphs are on different scales. Values with different superscripts are significantly different $(\mathrm{p}<0.05)$.

Given that $O$. vulgaris was able to grow during both thermal periods but showed better survival during the autumn-winter period, we performed the two following experiments in the autumn-winter period.

\section{Effects of salinity}

Throughout the whole experimental period, salinity remained approximately constant in each group: 33.98 $\pm 0.63(\mathrm{~S} 1$; control), $31.90 \pm 0.47(\mathrm{~S} 2)$, and $28.7 \pm 0.45$ (S3). Survival in all experimental groups was $100 \%$ (Table 1).

Octopus weight increased by more than $1 \mathrm{~kg}$ in all salinity conditions after 58 days, and no significant differences were observed for final weight or growth rates
(AGR, SGR) among salinity experimental conditions (Table 1).

The influence of salinity on feeding indices (AFR and SFR) was observed and both increased with salinity level. AFR data showed differences greater than 6 $\mathrm{g} \mathrm{day}^{-1}$ between the higher salinity levels (34 and 31.5) and the lowest (29). These differences were statistically significant. The specific feeding rate (SFR) showed the same pattern, and differences above $0.24 \%$ were observed, being statistically significant between 31.5 and 29 (Table 1).

Temperature decreased throughout the trials (initial mean temperature $21.2^{\circ} \mathrm{C}$, final mean temperature $13.3^{\circ} \mathrm{C}$ ). IFR and growth rates declined in parallel to temperature (Fig. 3A and 4). IFR data from the first 

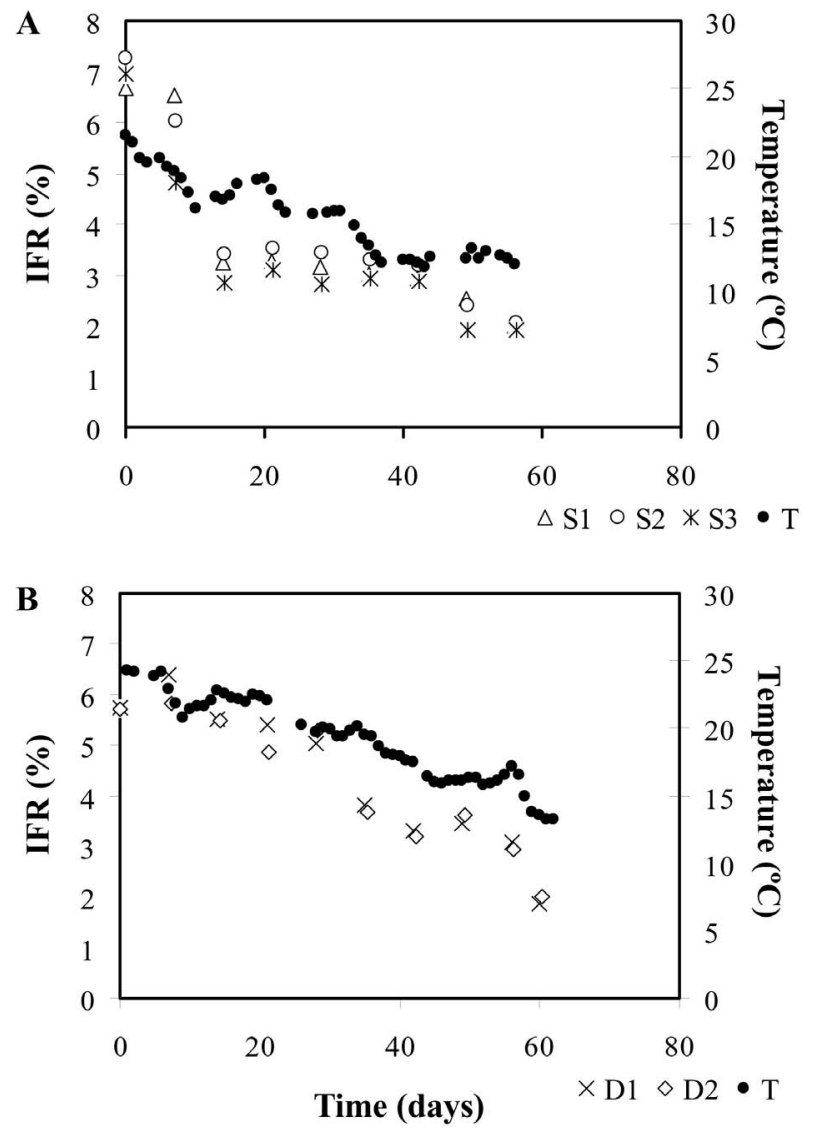

FIG. 3. - Weekly mean values of instantaneous specific feeding rate (IFR) and daily water temperature (T) during experimental periods 2 and 3. A, Experiment 2, effects of salinity: S1 (34), S2 (31.5) and S3 (29). B, Experiment 3, effects of culture density: D1 $\left(12 \mathrm{~kg} \mathrm{~m}^{-3}\right)$ and D2 $\left(24 \mathrm{~kg} \mathrm{~m}^{-3}\right)$.

two weeks (0-14 days) were statistically higher than data from the final two weeks (44-58 days) for all experimental conditions (ANOVA, $P<0.01$; Table 3 ). Growth (AGR) was also greater during the first experimental period $\left(0-29: 17.9^{\circ} \mathrm{C}\right)$ than the second one $(29-$ 58 days: $13.3^{\circ} \mathrm{C}$ ), regardless of salinity (Fig. 4 ).

\section{Effects of culture density}

Two initial densities were tested: D1 $\left(12.26 \mathrm{~kg} \mathrm{~m}^{-3}\right)$ and D2 $\left(24.13 \mathrm{~kg} \mathrm{~m}^{-3}\right)$. Final densities were $42.92 \pm 3.26$ $\mathrm{kg} \mathrm{m}^{-3}$ for D1 and $67.76 \pm 1.08 \mathrm{~kg} \mathrm{~m}^{-3}$ for D2 (Table 2), which in terms of total biomass translated into an increase of $247.24 \pm 20.70 \%$ and $180.84 \pm 2.78 \%$, respectively. After 60 days, survival was optimal for both experimental conditions, although slightly higher for D1 (96.6\%).

Final mean weight of octopuses cultivated under low density (D1; $2690.9 \pm 626.59 \mathrm{~g})$ was higher than that of octopuses cultivated under high density (D2; $2416.42 \pm 602.76 \mathrm{~g})(P<0.05$, Table 2). Growth rates showed higher values for D1, though these were not statistically different $(P>0.05$, Table 2$)$. In fact, based on the SGR values obtained for the different experimental groups (Table 2), it was estimated that the time

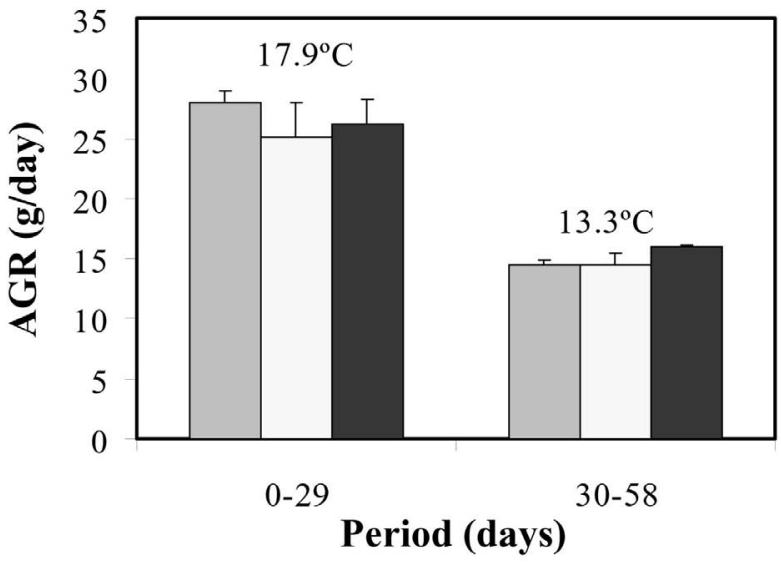

$\square \mathrm{S} 1 \square \mathrm{S} 2 \square \mathrm{S} 3$

FIG. 4. - Mean values \pm SD of absolute growth rate (AGR) and mean water temperature $\left({ }^{\circ} \mathrm{C}\right)$ for the periods comprised between 0-29 and 29-58 days (Experiment 2, effects of salinity: S1 (34), S2 (31.5) and S3 (29)).

TABLE 2. - Mean values \pm SD of every index for each experimental group in experiment 3 (effects of culture density). Wi, initial weight; Wf, final weight; Di, initial density; Df, final density; S, survival; AGR, absolute growth rate; SGR, specific growth rate; AFR, absolute feeding rate; SFR, specific feeding rate; n.s.= not significant.

\begin{tabular}{lccc}
\hline & D1 & D2 & t-test (p) \\
\hline Wi (g) & $803.17 \pm 146.84$ & $784.12 \pm 155.47$ & n.s. \\
Wf (g) & $2690.90 \pm 626.59$ & $2416.42 \pm 602.76$ & $<0.05$ \\
Di (kg m$\left.)^{-3}\right)$ & $12.36 \pm 0.48$ & $24.13 \pm 0.25$ & \\
Df $\left(\mathrm{kg} \mathrm{m}^{-3}\right)$ & $44.37 \pm 0.91$ & $67.76 \pm 1.08$ & \\
S $(\%)$ & $96.6 \%$ & $91.6 \%$ & \\
AGR $\left(\mathrm{g} \mathrm{day}^{-1}\right)$ & $31.95 \pm 3.72$ & $27.41 \pm 2.87$ & n.s. \\
SGR $(\%)$ & $2.03 \pm 0.14$ & $1.88 \pm 0.13$ & n.s. \\
AFR $\left(\mathrm{g} \mathrm{day}^{-1}\right)$ & $54.90 \pm 1.04$ & $45.96 \pm 5.00$ & $<0.05$ \\
SFR $(\%)$ & $3.13 \pm 0.22$ & $2.86 \pm 0.27$ & n.s. \\
\hline
\end{tabular}

TABLE 3. - Mean values of instantaneous specific feeding rate (IFR) \pm SD from the initial and final fortnight of experimental periods 2 (effects of salinity) and 3 (effects of culture density).

\begin{tabular}{llll}
\hline & \multicolumn{2}{c}{ IFR values \pm SD } & ANOVA (p) \\
Experiment 2 & $0-14$ days & $44-58$ days & \\
\hline S1 (34) & $5.02 \pm 2.16$ & $2.19 \pm 1.57$ & $<0.01$ \\
S2 (31.5) & $5.15 \pm 2.17$ & $2.41 \pm 2.05$ & $<0.01$ \\
S3 (29) & $3.91 \pm 1.90$ & $1.92 \pm 1.60$ & $<0.01$ \\
\hline Experiment 3 & $0-14$ days & $46-60$ days & \\
\hline D1 $\left(12 \mathrm{~kg} \mathrm{~m}^{-3}\right)$ & $5.92 \pm 1.02$ & $2.96 \pm 1.31$ & 0.00 \\
D2 $\left(24 \mathrm{~kg} \mathrm{~m}^{-3}\right)$ & $5.65 \pm 1.22$ & $2.96 \pm 1.34$ & 0.00 \\
\hline
\end{tabular}

needed for octopus to grow from an initial weight of $900 \mathrm{~g}$ to $3500 \mathrm{~g}$ was 69 days (D1) and 74 days (D2).

Feeding rates (AFR and SFR) were also higher at the lower density, with these differences being significant for AFR (Table 2). However, regardless of the density factor, we observed that the instantaneous feeding rate (IFR) decreased during the trials as temperature fell (initial temperature $24.2^{\circ} \mathrm{C}$, final temperature $13.2^{\circ} \mathrm{C}$; Fig. $\left.3 \mathrm{~B}\right)$. Significant differences $(P=0.00)$ were observed between IFR data from the first (0-14 days) and the final fortnight (46-60 days) (Table 3). 


\section{DISCUSSION}

Temperature is one of the main variables influencing growth and food intake in $O$. vulgaris. Within a range, temperature increases growth and feeding rates (Mangold, 1983). In our study, the bays of the Ebro Delta often experienced periods of one month above $25^{\circ} \mathrm{C}$ and two weeks at $28^{\circ} \mathrm{C}$ during summer, resulting in considerable weight losses and high mortality rates. On the other hand, the low temperatures reached in winter $\left(10^{\circ} \mathrm{C}\right.$ on two occasions) led to a lack of growth for this period. Therefore, the thermal range that defined the positive growth periods in the bays of the Ebro Delta was $19.5^{\circ} \mathrm{C}$ to $23^{\circ} \mathrm{C}$ (spring-summer) and $23.5^{\circ} \mathrm{C}$ to $12.3^{\circ} \mathrm{C}$ (autumnwinter). Our results agreed with those of Aguado and García (2002), who suggested an optimum range of $16^{\circ} \mathrm{C}$ to $21^{\circ} \mathrm{C}$ for commercially viable growth. According to our data, the autumn-winter period was more suitable for octopus growth; therefore, we planned all further experiments in this period. In these experiments, temperature dependence of growth and feeding rates was also clear. Figures 3 and 4, and Table 3, show how AGR and IFR decreased as temperature decreased. As in many other cultured species, these rates were proportionally higher in small individuals; thus, the effect of body weight on growth and feed intake cannot be dismissed (Aguado and García, 2002).

In our study octopus sizes corresponded to adults, and sexual maturation and fertilization could have taken place (Tirado et al., 2003). Sexual maturation in females and males involves different needs for nutrients and energy, because females have higher reproductive costs than males for egg formation (O'Dor and Wells, 1978). Moreover, spawning clearly influences female growth because females stop eating to take care of eggs. Shelters were therefore inspected daily to prevent the effects of spawning on female growth. Sexual maturation may well have had an effect on growth rates during the experiments but, as Aguado and García (2002) reported, it is practically impossible to separate the growth and food intake data related to sexual maturity, due to the lack of external morphological features that make it clear.

Salinity, like other abiotic factors including temperature, plays an important role in the distribution and catch probability of cephalopods. Fresh or estuarine waters are two habitats where cephalopods are poorly represented. Migratory responses as a function of salinity levels and temperature have been described (Bartol et al., 2002). About $O$. vulgaris, limited field observations have been published. Mangold (1983) reported a salinity range of 32-44 in the areas where the species is known to occur. Studies carried out in cages suspended from rafts in the Ria of Vigo, NW Spain, (Chapela et al., 2006) reported high mortalities in winter, when the salinity dropped below 29 , which is below the limit of tolerance described for this species by Mangold (1983). Sobrino et al. (2002) reported that heavy rainfalls caused landings of $O$. vulgaris to drop. These authors suggested that rainfall causes a decrease in salinity in coastal areas, but it can also increase water turbidity as well as concentration of pollutants such as pesticides used in agriculture due to terrestrial run-off.

The salinity range in the middle of Alfacs bay at a depth of 0.5-1 m (immersion depth of a floating cage designed for Alfacs bay; personal observation) is 2834 , while the surface shows minimum salinity values (0 m, 13.55; Fernández and Diogène, 2008). In our study we tested 3 salinities, one of them (control, S1: 34) within the range reported by Mangold (1983) and the other two (S2: 31.5; S3: 29) below the lower limit of this range. Overall, salinity affected neither survival nor growth, although feeding rates showed differences among salinities (Table 1). AFR and SFR showed a direct relationship with the salinity level, with the lowest value at the lowest salinity concentration (29). The physiological mechanisms by which $O$. vulgaris responds to osmotic stress have not been investigated. Molluscs such as bivalves respond by closing their valves or decreasing their branchial ventilation (Pierce, 1971). The decrease in feeding rates as salinity fell could be interpreted as a first symptom of hypoosmotic stress. However, these differences in AFR or SFR were not reflected in weight gain and as a result octopuses showed the same final growth rates and weight independently of salinity level. Growth and feeding rates were also similar to the data presented by García and Cerezo (2006) in their nutritional study carried out at a salinity level of 37 .

To date, limited information is available about the effect of culture density on ongrowing in tanks with an industrial focus. Numerous studies have analyzed physiological and nutritional aspects of octopus ongrowing in tanks, but all of them used one individual per tank (Aguado and García, 2002; García and Cerezo, 2006). Other studies have evaluated factors such as stocking density using cages suspended from rafts (Chapela et al., 2006) or floating cages (Rodríguez et al., 2006).

In this study, final culture density values were almost 4 and 3 times the initial density (D1: $12.36 \rightarrow$ $44.37 \mathrm{~kg} \mathrm{~m}^{-3}$; D2: $\left.24.13 \rightarrow 67.76 \mathrm{~kg} \mathrm{~m}^{-3}\right)$. The positive growth (AGR $>25 \mathrm{~g} \mathrm{day}^{-1}$ and $\mathrm{SGR}>1.5 \%$ ) and survival $(>90 \%)$ results obtained at high density $\left(24 \mathrm{~kg} \mathrm{~m}^{-3}\right)$ showed the advantages of our system as compared to that of Rodriguez et al. (2006) using floating cages, or that of Otero et al. (1999), who recommended that initial density should not exceed $10 \mathrm{~kg} \mathrm{~m}^{-3}$. On the other hand, our SGR results were similar to the ones obtained by García and Cerezo (2006) in their experiments with octopuses kept individually.

However, there were slight differences between the densities tested. The octopus is a territorial and competitive organism, and feeding and growth rates maintained an inverse relationship with density. In fact, final weights and growth rates were significantly higher at low density (D1: $2690.90 \pm 626.56 \mathrm{~g}$ ) than at high density (D2: $2416.42 \pm 602.76 \mathrm{~g}$ ) (see Table 2). Moreover, when we look at the time needed for on- 
growing, based on the values obtained for the SGR, it can be seen that group D2 took 5 days longer to reach optimal commercial weight than group D1. Specimens kept at low densities can more easily access food and suffer lower competition. In fact, feeding rates (AFR and SFR) showed higher values at low density.

On the other hand, high density induces competition for space, which stresses the animals and prevents smaller individuals from eating. Similarly, Rodríguez et al. (2006) observed that at a high initial density (24.5 $\mathrm{kg} \mathrm{m}^{-3}$ ) octopuses kept in cages consumed low amounts of food. Additionally, they observed a high incidence of skin lesions, which were more likely to occur due to friction with the cage walls and/or interactions among octopuses in a high-density culture. In our case, we did not observe any skin lesions, though the final density reached was higher $\left(67.76 \mathrm{~kg} \mathrm{~m}^{-3}\right)$.

Tank systems offer an alternative that allows for a more exhaustive control of culture, feeding, pathologies and environmental parameters (e.g. temperature, ammonia and nitrite concentrations). Moreover, tanks can accommodate water recirculation systems (Carbó et al., 2002) that include biological filters, oxygen and temperature regulators, and other devices that allow culture density to be increased or an ongrowing industry to be established in places with great environmental fluctuations.

The feeding and growth results obtained in this work allow us to define the most suitable ongrowing thermal periods for octopus in the bays of the Ebro Delta within the salinity range here tested (34-29). It can be also concluded that industrial ongrowing of $O$. vulgaris in tanks is promising. In order to optimize culture density, higher culture densities should be tried and the adaptation of recirculation systems should be investigated.

\section{ACKNOWLEDGEMENTS}

The authors wish to thank the JACUMAR Project "Optimización del engorde de pulpo (Octopus vulgaris)" for funding this research. We would like to thank the staff working at IRTA-Sant Carles de la Rápita, especially Josep Lluís Celades, for their technical assistance. We are indebted to Benjamín García and Jesús Cerezo (IMIDA) for their valuable advice. We are also grateful to Ricardo Sánchez (IEO).

\section{REFERENCES}

Aguado, F. and B. García. - 2002. Growth and food intake models in Octopus vulgaris Cuvier (1797): influence of body weight, temperature, sex and diet. Aquac. Int., 10: 361-377.

Bartol, I.K., R. Mann, and M. Vecchione. - 2002. Distribution of the euryhaline squid Lolliguncula brevis in Chesapeake Bay: Effects of selected abiotic factors. Mar. Ecol. Prog. Ser., 226: 235-247.

Boletzky, S.V. and R.T. Hanlon. - 1983. A review of the laboratory maintenance, rearing and culture of cephalopod molluscs. Mem. Natl. Mus. Vic., 44: 147-187.

Brett, J.R. - 1979. Environmental factors and growth. In: W.S. Hoar, D.J.Randall, and J.R. Brett (eds.), Fish Physiology,
Bioenergetics and Growth, Vol. 8, pp. 599-675. Academic Press, New York.

Camp, J. and M. Delgado. - 1987. Hidrografía de las bahías del delta del Ebro. Investig. Pesq., 51: 351-369.

Carbó, R., A. Estevez and M.D. Furones. - 2002. Intelligent and multifunctional recirculation system. Its application in research at CA-IRTA. In: Seafarming -Today and Tomorrow Conference. Trieste, Italy (October 2002).

Cerezo, J. and B. García. - 2005. Suitable dissolved oxygen levels for common octopus (Octopus vulgaris Cuvier, 1797) at different weights and temperatures: analysis of respiratory behaviour. Aquaculture, 244 (1-4): 303-314.

Chapela, A., A.F. González, E.G. Dawe, F.J. Rocha and A. Guerra. -2006 . Growth of common octopus (Octopus vulgaris) in cages suspended from rafts. Sci. Mar., 70(1): 121-129.

Fernández, M. and J. Diogène. - 2008. Salinitats al punt central interior de la Badia dels Alfacs durant l'any 2008. Resultats del programa de seguiment de la qualitat de les aigües, mol-luscs i fitoplancton tòxic a les zones de producció de marisc al litoral cátala de la DGPiAM.

García, B. and F. Aguado. - 2002. Influence of diet on ongrowing and nutrient utilization in the common octopus (Octopus vulgaris). Aquaculture, 211: 171-182.

García, B. and J. Cerezo. - 2004. Influencia del número de días de ayuno a la semana sobre el crecimiento, el índice de conversión y la supervivencia del pulpo de roca (Octopus vulgaris, Cuvier 1797). AquaTIC, 21: 34-41.

García, B. and J. Cerezo. - 2006. Optimal proportions of crabs and fish in diet for common octopus (Octopus vulgaris) ongrowing. Aquaculture, 253: 502-511.

Hartwick, E.B., R.F. Ambrose and S.M.C. Robinson. - 1984. Dynamics of shallow-water populations of Octopus dofleini. Mar. Biol., 82: 65-72.

Iglesias, J., F.J. Sánchez and J.J. Otero. - 1997. Primeras experiencias sobre el cultivo integral del pulpo (Octopus vulgaris) en el Instituto Español de Oceanografía. In: J. Costa, E. Abellán, B. García García, A. Ortega, S. Zamora (eds.), Actas del VI Congreso Nacional de Acuicultura, pp. 221-226. MAPA, Madrid.

Iglesias, J., J.J. Otero, C. Moxica, L. Fuentes and F.J. Sánchez. - 2004. The completed life cycle of the octopus (Octopus vulgaris, Cuvier) under culture conditions: paralarvae rearing using Artemia and zoeae, and first data on juvenile growth up to 8 months of age. Aquac. Int., 12: 481-487.

Mangold, K. - 1983. Octopus vulgaris. In: P.R. Boyle (ed.), Cephalopod Life Cycles, vol. I, pp. 335-364. Academic Press, London.

O'Dor, R.K. and M.J. Wells. - 1978. Reproduction versus somatic growth: hormonal control in Octopus vulgaris. J. Exp. Biol., 77: 529-540.

Otero, J.J., C. Moxica, F.J. Sánchez and J. Iglesias. - 1999. Engorde de pulpo (Octopus vulgaris Cuvier) a diferentes densidades de estabulación. In: MAPA (ed.), Libro de resúmenes del VII Congreso Nacional de Acuicultura. MAPA, Madrid.

Pierce, S.K., $J_{R}$. - 1971. Volume regulation and valve movements by marine mussels. Comp. Biochem. Physiol. 39 (A): 103-117.

Ramón M., M. Fernández and E. Galimany. - 2007. Development of mussel (Mytilus galloprovincialis) seed from two different origins in a semi-enclosed Mediterranean Bay (N.E. Spain). Aquaculture, 264(1-4): 148-159.

Rodríguez, C., J.F. Carrasco, J.C. Arronte and M. Rodríguez. 2006. Common octopus (Octopus vulgaris Cuvier, 1797) juvenile ongrowing in floating cages. Aquaculture, 254: 293-300.

Sobrino, I., L. Silva, J.M. Bellido and F. Ramos. - 2002. Rainfall, river discharges and sea temperature as factors affecting abundance of two coastal benthic cephalopod species in the gulf of Cádiz (SW Spain). Bull. Mar. Sci., 71(2): 851-865.

Snedecor, G.W. and W.G. Cochran. - 1980. Métodos estadísticos. Cía Ed. Continental, Buenos Aires.

Tirado, C., Rodríguez, A., Bruzón, M.A., López, J.I., Salas, C. and I. Márquez. - 2003. La reproducción del pulpo (Octopus vulgaris) y el choco (Sepia officinalis) en la costa andaluza. Junta de Andalucía (Consejería de Agricultura y Pesca), Sevilla.

Scient. ed.: P. Sánchez.

Received November 2, 2009. Accepted May 7, 2010.

Published online November 13, 2010. 